\title{
Bacillus haloalkaliphilus sp. nov.
}

\author{
DAGMAR FRITZE* \\ DSM-Deutsche Sammlung von Mikroorganismen und Zellkulturen $\mathrm{GmbH}$, \\ D-38124 Braunschweig, Germany
}

\begin{abstract}
Ten obligately alkaliphilic, extremely halotolerant Bacillus isolates were studied and compared with strain WN13 $^{\mathrm{T}}$ ( $\mathrm{T}=$ type strain), an earlier isolate provided by $H$. G. Trüper. All of these strains produced round, terminally located spores in swollen sporangia. DNA-DNA hybridization values (78 to $91 \%$ ) and phenotypic similarity analyses revealed that 10 of the 11 strains formed a relatively homogeneous group, and although one strain (strain AH/6/1) could not be distinguished phenotypically, it exhibited hybridization values of only 46 to 47\%. This group of strains is sufficiently different from all previously validly described Bacillus species in its morphological, physiological, and biochemical properties that a separate species is considered appropriate, for which the name Bacillus haloalkaliphilus sp. nov. is proposed.
\end{abstract}

Increased industrial interest in alkaliphilic organisms, especially members of the genus Bacillus, long after the original description of Bacillus alcalophilus (21), has resulted in the isolation of numerous strains. To date, a number of approaches have been used to define this heterogeneous group taxonomically $(7,9,16)$. This has led to valid descriptions of additional alkaliphilic Bacillus species, including Bacillus cohnii (20) and Bacillus agaradhaerens, Bacillus clarkii, Bacillus clausii, Bacillus gibsonii, Bacillus halmapalus, Bacillus halodurans, Bacillus horikoshii, Bacillus pseudalcaliphilus, and $\mathrm{Ba}$ cillus pseudofirmus (15). A more physiological and ecological approach to these organisms is the question of how life at $\mathrm{pH}$ values above 9 or even 10 or 11 is possible (10).

In 1985 isolation of obligately alkaliphilic, extremely halotolerant Bacillus sp. strain WN13 ${ }^{\mathrm{T}}(\mathrm{T}=$ type strain) from the lakes of Wadi Natrun in Egypt was described, and the method of osmoregulation in this organism was discussed $(14,23)$. In a study of the taxonomy of 78 alkaliphilic Bacillus strains (6), Wadi Natrun strain $\mathrm{WN} 13^{\mathrm{T}}$ was the only isolate that produced round spores and exhibited extreme halotolerance. Differences in phenotypic properties and low levels of DNA-DNA hybridization with other alkaliphilic strains, as well as neutrophilic Bacillus species, suggested that this strain may represent a new species. After similar alkaliphilic, halophilic strains that form round spores were isolated, a more detailed study of the taxonomic position of this group of organisms was undertaken.

\section{MATERIALS AND METHODS}

Bacterial strains. The Bacillus strains used in this study and their sources are listed in Table 1. Strain WN13 ${ }^{\mathrm{T}}$ was provided by H. G. Trüper, Bonn, Germany. Additional haloalkaliphilic strains were isolated from brine and dried soil, mud and dung samples which were collected in 1992 from various places in the Wadi Natrun by D. Claus. Type strains and other representative strains used for reference purposes were obtained from the DSM-Deutsche Sammlung von Mikroorganismen und Zellkulturen $\mathrm{GmbH}$.

Enrichment and isolation. Portions $(0.5 \mathrm{~g})$ of the samples (Table 1) were soaked and dissolved in 5-ml portions of alkaline nutrient broth supplemented with $20 \%$ (final concentration) $\mathrm{NaCl}$. The resulting preparations were incubated overnight at $40^{\circ} \mathrm{C}$. Loopfuls from these enrichment cultures were streaked onto agar plates containing the same medium, and the plates were incubated at $40^{\circ} \mathrm{C}$ for 2 to 3 days until distinctive colonies were visible. Three or four colonial types developed, and whitish or yellowish colonies that were 1 to $2 \mathrm{~mm}$ in diameter and had smooth to matt surfaces were selected and examined with a microscope. These colonies usually consisted of slender cells that were approximately 0.4 by $7 \mu \mathrm{m}$. When these organisms were plated onto alkaline nutrient agar supple-

* Mailing address: DSM-Deutsche Sammlung von Mikroorganismen und Zellkulturen GmbH, Mascheroder Weg 1b, D-38124 Braunschweig, Germany. Phone: 49-531-2616-254. Fax: 49-531-2616-418. mented with $5 \% \mathrm{NaCl}$, the colonies that developed contained cells which produced round, terminally located spores in swollen sporangia.

Phenotypic characterization. Phenotypic characteristics were determined largely by the methods of Gordon et al. (8), as described previously (20), with the additional modification that test media were supplemented with $5 \% \mathrm{NaCl}$. Two media buffered with either phosphate or citrate were used to test for tolerance to pH 7.

Chemosystematic characterization. The following analyses were performed by using previously described methods: cell wall analysis (11), fatty acid analysis (17), and quinone analysis (12).

DNA isolation, base composition, and DNA-DNA hybridization. DNA was isolated and DNA hybridization experiments were performed as described by Spanka and Fritze (20). The $\mathrm{G}+\mathrm{C}$ content of the DNA was determined by the buoyant density method $(7)$, spectrophotometrically $(20)$, or by high-performance liquid chromatography (HPLC) (13).

\section{RESULTS}

DNA base composition and DNA-DNA hybridization. $\mathrm{G}+\mathrm{C}$ contents of some representative strains were as follows: strain WN13 ${ }^{\mathrm{T}}$ (= DSM $5271^{\mathrm{T}}$ ), $37.1 \mathrm{~mol} \%$ as determined by the buoyant density method and $37.5 \mathrm{~mol} \%$ as determined by HPLC; strain AH/1 (= DSM 9473), $37.9 \mathrm{~mol} \%$ as determined by HPLC; and strain AH/6/1 (= DSM 9478), $39.0 \mathrm{~mol} \%$ as determined by HPLC. A direct comparison of the melting curves of the DNAs of these strains revealed that their melting points differed by at most, $0.4^{\circ} \mathrm{C}$, which reflected a difference in $\mathrm{G}+\mathrm{C}$ contents of $1 \mathrm{~mol} \%$.

Of the 10 haloalkaliphilic isolates that formed round spores, 9 exhibited DNA-DNA reassociation values between 78 and $91 \%$ with reference strain WN13 $13^{\mathrm{T}}$ (= DSM $5271^{\mathrm{T}}$ ). One isolate, strain AH/6/1 (= DSM 9478), exhibited a level of hybridization with $\mathrm{WN} 13^{\mathrm{T}}$ of only 46 to $47 \%$.

Cellular fatty acid composition, quinone system, and cell walls. Whole-cell fatty acid patterns were determined by using nonsporulated cells grown at $30^{\circ} \mathrm{C}$ on plates containing Trypticase soy broth (BBL) agar supplemented with 5 and $0.5 \%$ $\mathrm{NaCl}$. The fatty acid patterns were only insignificantly different when the salt concentration was $0.5 \%$. In the presence of $5 \%$ $\mathrm{NaCl}$ the major fatty acids in all of the strains were saturated branched-chain fatty acids (iso- $\mathrm{C}_{15: 0}, 40$ to $59 \%$ [mean, $48 \%$ ]; anteiso- $\mathrm{C}_{15: 0}, 6$ to $15 \%$ [mean, $11 \%$ ]; iso- $\mathrm{C}_{17: 0}, 4$ to $8 \%$ [mean, $6 \%$ ]; anteiso- $\mathrm{C}_{17: 0}, 6$ to $15 \%$ [mean, $11 \%$ ]). Low levels of unsaturated fatty acids were also present $\left(\mathrm{C}_{16: 1}\right.$ and $\mathrm{C}_{17: 1}$ accounted for 15 to $24 \%$ of the fatty acids [mean, 19\%]). When the cells were grown in the presence of an $\mathrm{NaCl}$ concentration of $0.5 \%$, the amounts of iso- $\mathrm{C}_{15: 0}$, anteiso- $\mathrm{C}_{15: 0}$, and anteiso$\mathrm{C}_{17: 0}$ were slightly higher $(4,3$, and $2 \%$ higher, respectively), whereas the amounts of iso- $C_{17: 0}$ and $C_{17: 1}$ were slightly lower ( 3 and 5\% lower, respectively). 
TABLE 1. Haloalkaliphilic Bacillus strains examined in this study

\begin{tabular}{lll}
\hline \multicolumn{1}{c}{ Strain } & $\begin{array}{c}\text { Other } \\
\text { designation }\end{array}$ & \multicolumn{1}{c}{$\begin{array}{c}\text { Source at Wadi } \\
\text { Natrun }^{a}\end{array}$} \\
\hline DSM 5271 & $\mathrm{WN13}$ & Brine and mud \\
DSM 9473 & $\mathrm{AH} / 1$ & Camel dung \\
DSM 9474 & $\mathrm{AH} / 2$ & Sandy loam \\
DSM 9475 & $\mathrm{AH} / 3$ & Solid loam \\
DSM 9476 & $\mathrm{AH} / 4$ & Solid loam \\
DSM 9477 & $\mathrm{AH} / 5$ & Loamy sand \\
DSM 9478 & $\mathrm{AH} / 6 / 1$ & Solid loam \\
DSM 9479 & $\mathrm{AH} / 7 / 2$ & Camel dung \\
DSM 9480 & $\mathrm{AH} / 8$ & Solid briny loam \\
DSM 9481 & $\mathrm{AH} 10 / 1$ & Briny sand \\
DSM 9482 & $\mathrm{AH} / 11$ & Salt crystal \\
\hline
\end{tabular}

${ }^{a}$ Strain WN13 ${ }^{\mathrm{T}}$ was obtained from H. G. Trüper, Universität Bonn, Bonn, Germany; all of the other strains were isolated in this study.

The major quinone of strain WN13 ${ }^{\mathrm{T}}\left(=\mathrm{DSM} 5271^{\mathrm{T}}\right)$ was MK-7, which accounted for $>90 \%$ of the total quinones. A small amount of MK-6 (about 8\%) was also found.

The walls of vegetative cells of all 11 strains tested contained diaminopimelic acid.

Phenotypic characterization. The slender vegetative cells of the alkaliphilic, extremely halotolerant isolates were 0.3 to 0.5 $\mu \mathrm{m}$ wide and 3 to $8 \mu \mathrm{m}$ long. The spores were round and were produced terminally, swelling the sporangia (Fig. 1). The colonies were cream white on alkaline nutrient agar supplemented with 5 to $15 \% \mathrm{NaCl}$. A slight yellowish color occurred on nutrient agar containing $20 \% \mathrm{NaCl}$. Most strains also formed more translucent colonies which contained nonsporulated or poorly sporulated cells. Sporulation was enhanced at $\mathrm{NaCl}$ concentrations close to $5 \%$ and was delayed at higher concentrations. Cell morphology and growth were strongly influenced by $\mathrm{NaCl}$ concentrations (Fig. 1). On media without additional $\mathrm{NaCl}$ or with only $0.5 \% \mathrm{NaCl}$, no growth or only very weak growth occurred, and under the microscope the cells appeared to be wrinkled, interwoven filaments.

The strains tested in this study were positive for oxidase and catalase reactions, growth at 15 and $40^{\circ} \mathrm{C}$ (at $45^{\circ} \mathrm{C}$ strains $\mathrm{WN} 13^{\mathrm{T}}, \mathrm{AH} / 3$, and $\mathrm{AH} / 10 / 1$ did not grow and the growth of strain $\mathrm{AH} / 11$ was delayed), growth in the presence of $20 \%$ $\mathrm{NaCl}$ (in the presence of $25 \% \mathrm{NaCl}$ strains $\mathrm{AH} / 4$ and $\mathrm{AH} / 5$ did not grow and the growth of strain $\mathrm{AH} / 2$ was variable), growth on defined medium at $\mathrm{pH} 8$ and 9.7, hydrolysis of gelatin (most strains exhibited weak hydrolysis), weak hydrolysis of starch (very narrow [2- to 3-mm] clearing zones formed around colonies after 10 days; strains $\mathrm{AH} / 6 / 1$ and $\mathrm{AH} / 10 / 1$ were negative), hydrolysis of hippurate, and cleaving of 4-methyl-umbelliferone glucuronide.

The strains tested in this study were negative for the $\mathrm{KOH}$ and aminopeptidase reactions, growth at 5 and $10^{\circ} \mathrm{C}$, growth in nutrient media not supplemented with $\mathrm{NaCl}$ (very weak, variable growth occurred in some cases), growth at $\mathrm{pH} 7$, hydrolysis of casein (strains $\mathrm{WN} 13^{\mathrm{T}}$ and $\mathrm{AH} / 8$ were positive; strains $\mathrm{AH} / 3$ and $\mathrm{AH} / 4$ were weakly positive), hydrolysis of Tween 20 and Tween 80 , hydrolysis of pullulan, the lecithinase reaction, reduction of nitrate to nitrite, and cleavage of urea.

\section{DISCUSSION}

After the extremely halotolerant, obligately alkaliphilic strain WN13 $13^{\mathrm{T}}$ was isolated from Wadi Natrun briny mud, it was used as a model organism to study the physiological strategies which allow an organism to survive in the presence of $\mathrm{NaCl}$ concentrations of $20 \%$ or more (23). Compatible solutes
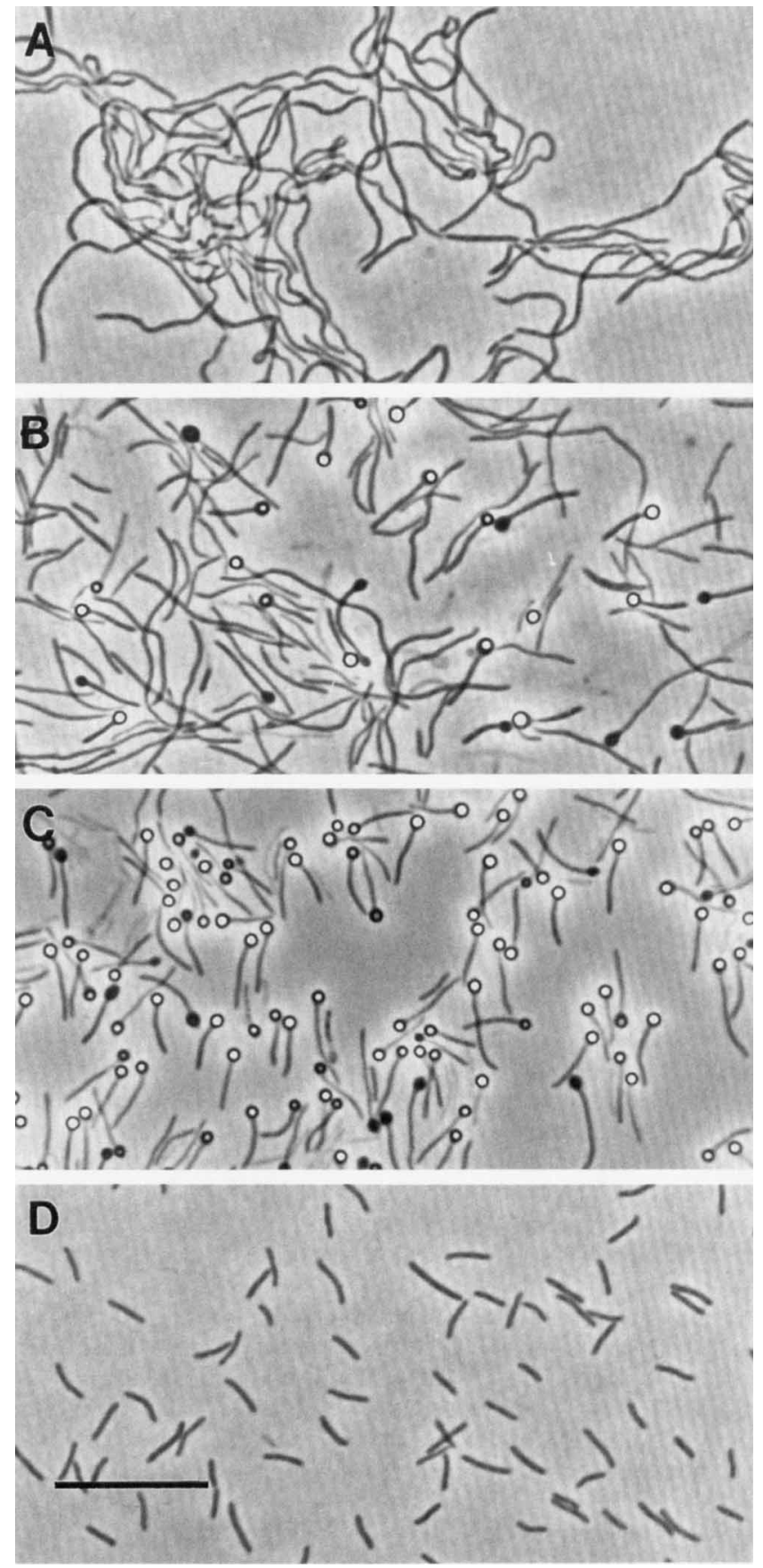

FIG. 1. B. haloalkaliphilus cell morphology after growth for 3 days in nutrient broth (pH 9.7) containing $\mathrm{NaCl}$ at different concentrations. (A) Strain DSM $5271^{\mathrm{T}}, 0.5 \% \mathrm{NaCl}$. (B) Strain DSM $5271^{\mathrm{T}}, 5 \% \mathrm{NaCl}$. (C) Strain DSM $9473,5 \%$ NaCl. (D) Strain DSM 5271, $10 \% \mathrm{NaCl}$. Bar $=10 \mu \mathrm{m}$.

help the organisms to resist osmotic stress, and it was shown that strain $\mathrm{WN} 13^{\mathrm{T}}$ accumulated different solutes when it was grown on complex media containing high salt concentrations, whereas it synthesized mainly ectoine when it was grown on mineral medium having a salt concentration of $10 \%$ (14). When betaine was offered as a compatible solute in the culture medium, this compound was taken up and accumulated rather than the strain synthesizing its own metabolites. Weisser and Trüper tried to classify strain WN13 ${ }^{\mathrm{T}}$, largely on the basis of its 
TABLE 2. Characteristics of B. haloalkaliphilus and physiologically or morphologically similar Bacillus species

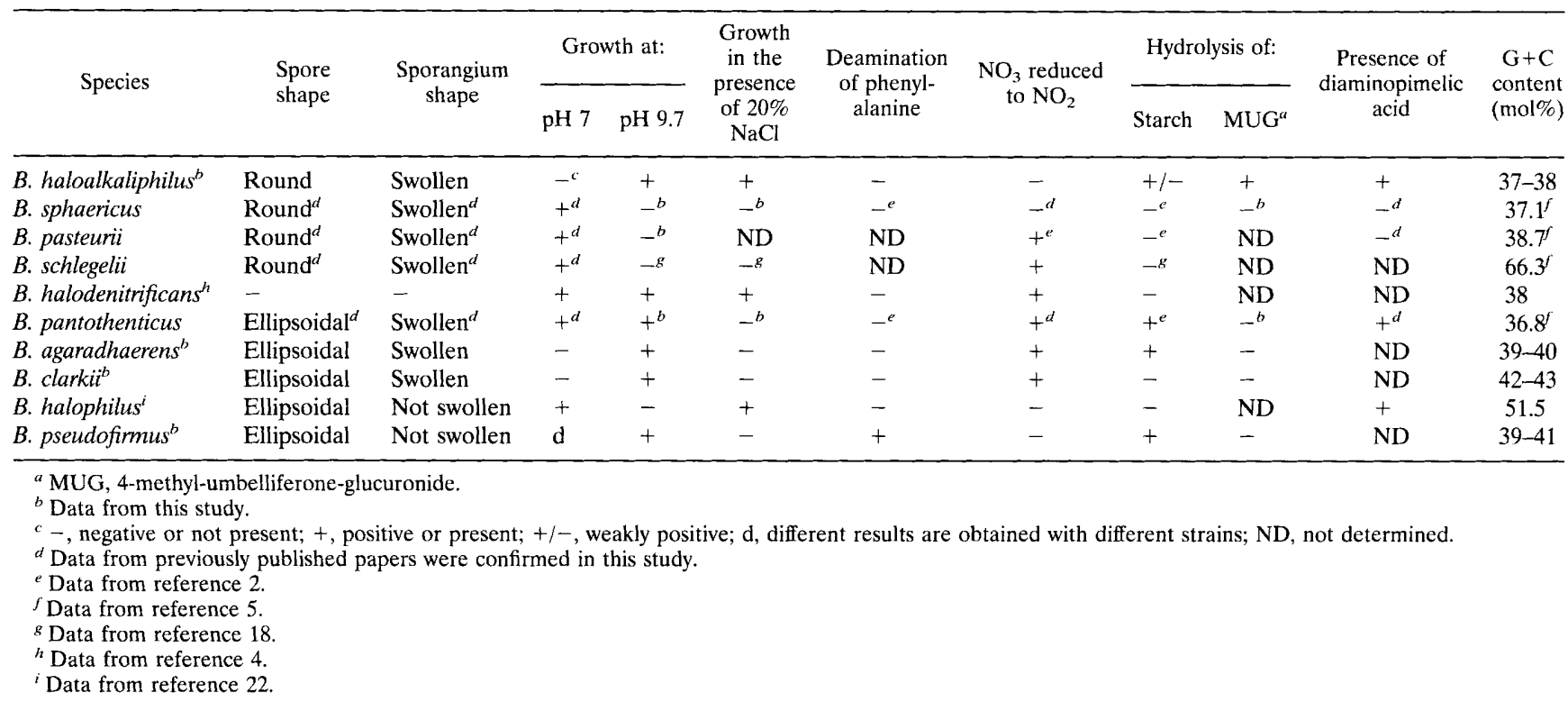

alkaliphily, and found that it clearly differed from the only validly described alkaliphilic Bacillus species available at that time, B. alcalophilus (21), and another alkaliphilic Bacillus taxon that had not been validly described, " $B$. alcalophilus subsp. halodurans" (1). These findings were later confirmed (6).

The conspicuous properties of $\mathrm{WN} 13^{\mathrm{T}}$ include the shape and localization of the spores, as well as the shape of the sporangium; similar characteristics are found in only three other Bacillus species. However, in contrast to Bacillus sphaericus and Bacillus pasteurii, which also produce spherical spores that clearly distend the sporangium, the walls of strain $\mathrm{WN} 13^{\mathrm{T}}$ vegetative cells contain diaminopimelic acid. The cell wall composition of Bacillus schlegelii, an organism that can grow chemoautotrophically, is not known, but a number of properties, including its $\mathrm{G}+\mathrm{C}$ content $(66.3 \mathrm{~mol} \%$, as determined by the buoyant density method), clearly differentiate this organism from the strains used in this study. The presence of diaminopimelic acid in its cell walls also distinguishes $\mathrm{WN}^{3} 3^{\mathrm{T}}$ from Bacillus globisporus, Bacillus insolitus, Bacillus marinus, and Bacillus psychrophilus; in addition, the spores of these species are not wider (or not clearly wider) than the vegetative cells.

Few Bacillus species that grow in the presence of $\mathrm{NaCl}$ concentrations of $20 \%$ or more and/or are obligately alkaliphilic have been described. It has been reported that Bacillus halophilus (22) tolerates up to $30 \%$ total salts, grows at $\mathrm{pH} 6$ to 8 , and has an optimum $\mathrm{pH}$ of around 7. Bacillus halodenitrificans (4), which was described as an organism that does not form spores, grows at $\mathrm{pH} 5.8$ to $>9.6$ and has an optimum $\mathrm{pH}$ of $7.4 ; \mathrm{NaCl}$ concentrations up to $25 \%$ are tolerated by this organism. Bacillus pantothenticus grows at $\mathrm{pH} 9.7$ but not in the presence of an $\mathrm{NaCl}$ concentration of $20 \%$ (only up to $10 \%$ $\mathrm{NaCl}$ reported as positive). The highest $\mathrm{NaCl}$ concentration at which three recently described alkaliphilic Bacillus species (16) definitely grow is $16 \%$, and a few strains tolerate up to $18 \%$ $\mathrm{NaCl}$. Two of these organisms, B. agaradhaerens and B. clarkii, are obligately alkaliphilic organisms whose optimum $\mathrm{pH}$ is around 10. B. pseudofirmus has an optimum $\mathrm{pH}$ of around 9, and a few strains grow at $\mathrm{pH} 7$. None of these organisms produces round spores. Table 2 shows the relevant properties of morphologically or physiologically similar Bacillus species.

In previous studies $(6,7)$ a number of DNA-DNA hybridization experiments were performed with strain $\mathrm{WN} 13^{\mathrm{T}}$ and the type strains or representative strains of morphologically or physiologically similar Bacillus species that have similar $\mathrm{G}+\mathrm{C}$ compositions. None of the hybridization values obtained indicated that strain $\mathrm{WN} 13^{\mathrm{T}}$ belongs to a previously described species. The levels of binding (3) with strain WN13 ${ }^{\mathrm{T}}$ DNA were as follows: B. alcalophilus DSM $485^{\mathrm{T}}, 29 \% ; B$. lentus DSM 9T , 32\%; B. cohnii DSM 2528, 25\%; B. cohnii DSM 6362, $24 \%$; B. marinus DSM $1297^{\mathrm{T}}, 15 \% ; B$. sphaericus DSM $28^{\mathrm{T}}$, $23 \%$; $B$. pasteurii DSM $33^{\mathrm{T}}, 22 \%$; and $B$. globisporus DSM $4^{\mathrm{T}}$, $28 \%$.

Considerable advances have been made in the taxonomy of the genus Bacillus as a result of modern methods. However, the results obtained with these methods have also underscored the significance of features such as spore shape and position and shape of the sporangium, as well as physiological and biochemical properties. Despite the fact that certain morphological and physiological types may not consistently be monophyletic, the data presented in this study show that the new isolates which I studied represent a novel species belonging to the genus Bacillus as it is currently defined.

It has been recommended that a species description should be based on at least 10 isolates to show the variation within a taxon (19). Therefore, the group of strains studied here is considered to be genetically and phenotypically distinct, and the name Bacillus haloalkaliphilus sp. nov. is proposed below for this group of organisms.

Description of Bacillus haloalkaliphilus sp. nov. Bacillus haloalkaliphilus (hal.o.al.ka.li'phi.lus. Gr. n. hals, salt; Arabic n. al qaliy, soda ash; Gr. adj. philos, loving; M.L. adj. haloalkaliphilus, loving briny and alkaline media). Cells are gram positive (as determined by the $\mathrm{KOH}$ and aminopeptidase tests). The cells are 0.3 to $0.5 \mu \mathrm{m}$ wide and 3 to $8 \mu \mathrm{m}$ long. Motile. Spores are round and located terminally. Sporangia are swollen. On alkaline nutrient agar supplemented with 5 to $10 \%$ $\mathrm{NaCl}$ the colonies are creme white. In the presence of $20 \%$ $\mathrm{NaCl}$ the colonies are slightly yellowish. 
The major cellular fatty acids are the saturated branchedchain fatty acids iso- $\mathrm{C}_{15: 0}(48 \%)$, anteiso- $\mathrm{C}_{15: 0}(11 \%)$, anteiso$\mathrm{C}_{17: 0}(11 \%)$, and iso- $\mathrm{C}_{17: 0}(6 \%)$. A small amount $(19 \%)$ of unsaturated fatty acids is also present. MK-7 is the major menaquinone ( $>90 \%$ of the total quinones). Ubiquinones are not present. The peptidoglycan side chains are directly linked via $m$-diaminopimelic acid.

Chemoorganotrophic. Does not grow (or grows only very poorly) in nutrient broth or on nutrient agar without $\mathrm{NaCl}$. Catalase positive. Oxidase positive. Mesophilic. Three strains do not grow at $45^{\circ} \mathrm{C}$; no growth occurs at $50^{\circ} \mathrm{C}$. Obligately alkaliphilic. No growth occurs at $\mathrm{pH} 7$, and good growth occurs at $\mathrm{pH}$ 9.7. Halophilic and extremely halotolerant. Growth occurs in the presence of up to $25 \% \mathrm{NaCl}$ (two strains are negative under these conditions); no growth or only very weak growth occurs without added $\mathrm{NaCl}$. Hydrolysis of starch is weak, and pullulan is not hydrolyzed. Gelatin is hydrolyzed. No hydrolysis or only weak hydrolysis of casein occurs. Hippurate is hydrolyzed. Tween 20 and Tween 80 are not hydrolyzed. Nitrate is not reduced to nitrite. Egg yolk lecithinase negative. 4-Methyl-umbelliferone-glucuronide is hydrolyzed. Urea is not cleaved.

The DNA base composition of type strain WN13 (= DSM 5271 ) is $37 \mathrm{~mol} \%$ (as determined by the buoyant density method) to $38 \mathrm{~mol} \%$ (as determined by HPLC). Isolated from alkaline, highly saline mud from Wadi Natrun, Egypt.

\section{ACKNOWLEDGMENTS}

I thank Preben Nielsen for performing the fatty acid analysis and Jutta Burghardt, Carola Henze, and Katja Weisser for valuable technical assistance.

\section{REFERENCES}

1. Boyer, E., M. B. Ingle, and G. D. Mercer. 1973. Bacillus alcalophilus subsp halodurans subsp. nov.: an alkaline-amylase-producing alkalophilic organism. Int. J. Syst. Bacteriol. 23:238-242.

2. Claus, D., and R. C. W. Berkeley. 1986. Genus Bacillus Cohn 1872, p. 1105-1139. In P. H. A. Sneath, N. S. Mair, M. E. Sharpe, and J. G. Holt (ed.) Bergey's manual of systematic bacteriology, vol. 2. Williams \& Wilkins, Baltimore.

3. De Ley, J., H. Cattoir, and R. Reynaerts. 1970. The quantitative measurement of DNA hybridisation from renaturation rates. Eur. J. Biochem. 12: 133-142.

4. Denariaz, G., W. J. Payne, and J. Le Gall, 1989. A halophilic denitrifier, Bacillus halodenitrificans sp. nov. Int. J. Syst. Bacteriol. 39:145-151.
5. Fahmy, F. A., J. Flossdorf, and D. Claus. 1985. The DNA base composition of the type strains of the genus Bacillus. Syst. Appl. Microbiol. 6:60-65.

6. Fritze, D. 1985. Taxonomische Untersuchungen an alkaliphilen BacillusStämmen. Ph.D. thesis. University of Göttingen, Gottingen, Germany.

7. Fritze, D., J. Flossdorf, and D. Claus. 1990. Taxonomy of alkaliphilic Bacillus strains. Int. J. Syst. Bacteriol. 40:92-97.

8. Gordon, R. E., W. C. Haynes, and C. H. Pang. 1973. The genus Bacillus. Agricultural Handbook no. 427. U. S. Department of Agriculture, Washington, D. C.

9. Gordon, R. E., and J. L. Hyde. 1982. The Bacillus firmus - Bacillus lentus complex and $\mathrm{pH} 7.0$ variants of some alkalophilic strains. J. Gen. Microbiol. 128:1109-1116.

10. Jones, B. E., W. D. Grant, N. C. Collins, and W. E. Mwatha. 1994. Alkaliphiles: diversity and identification, p. 195-230. In F. Priest, A. RamosCormenzana, and B. J. Tindall (ed.), Bacterial diversity and systematics. Plenum Press, New York.

11. Kandler, O., and N. Weiss. 1986. Genus Lactobacillus (Beijerinck 1901), p. 1209-1219. In P. H. A. Sneath, N. S. Mair, M. E. Sharpe, and J. G. Holt (ed.), Bergey's manual of systematic Bacteriology, vol. 2. Williams \& Wilkins, Baltimore.

12. Kroppenstedt, R. M. 1982 . Separation of bacterial menaquinones by HPLC using reverse phase (RP18) and a silver loaded ion exchanger as stationary phases. J. Liq. Chromatogr. 5:2359-2367.

13. Meshbah, M., U. Premachandran, and W. Whitman. 1989. Precise measurement of the $\mathrm{G}+\mathrm{C}$ content of deoxyribonucleic acid by high-performance liquid chromatography. Int. J. Syst. Bacteriol. 39:159-167.

14. Müller, E. 1991. Kompatible Solute und Prolingewinnung bei halophilen und halotoleranten Bacilli. Ph.D. thesis. University of Bonn, Bonn, Germany.

15. Nielsen, P., D. Fritze, and F. Priest. 1995. Phenetic diversity of alkaliphilic Bacillus strains: proposal for nine new species. Microbiology 141:1745-1761.

16. Nielsen, P., F. A. Rainey, H. Outtrup, F. G. Priest, and D. Fritze. 1994. Comparative 16S rDNA sequence analysis of some alkaliphilic bacilli and the establishment of a sixth rRNA group within the genus Bacillus. FEMS Microbiol. Lett. 117:61-66.

17. Sasser, M. 1990 . Identification of bacteria by gas chromatography of cellular fatty acids. U. S. Fed. Culture Collections Newsl. 20:1-5.

18. Schenk, A., and M. Aragno. 1979. Bacillus schlegelii, a new species of thermophilic, facultatively chemolithoautotrophic bacterium oxidizing molecular hydrogen. J. Gen. Microbiol. 115:333-341.

19. Sneath, P. H. A. 1977. The maintenance of large numbers of strains of microorganisms, and the implication for culture collections. FEMS Microbiol. Lett. 1:333-334.

20. Spanka, R., and D. Fritze. 1993. Bacillus cohnii sp. nov., a new, obligately alkaliphilic, oval-spore-forming Bacillus species with ornithine and aspartic acid instead of diaminopimelic acid in the cell wall. Int. J. Syst. Bacteriol. 43:150-156.

21. Vedder, A. 1934. Bacillus alcalophilus n. sp.; benevens enkele ervaringen met sterk alcalische voedingsbodems. Antonie Leeuwenhoek 1:143-147.

22. Ventosa, A., M. T. Garcia, M. Kamekura, H. Onishi, and F. Ruiz-Berraquero. 1990. Bacillus halophilus sp. nov., a moderately halophilic Bacillus species. Int. J. Syst. Bacteriol. 40:105.

23. Weisser, J., and H.-G. Trüper. 1985. Osmoregulation in a new haloalkaliphilic Bacillus from the Wadi Natrun (Egypt). Syst. Appl. Microbiol. 6:7-11. 